\title{
PERKEMBANGAN SURAT KABAR LOKAL DI MADIUN TAHUN 1999-2011
}

\author{
Aditya Nur Hanafi \& Abraham Nurcahyo*
}

\begin{abstract}
Abstrak
Pendekatan yang digunakan dalam penelitian ini adalah pendekatan kualitatif. Jenis pendekatannya adalah pendekatan studi kasus. Penelitian studi kasus ini dapat membantu peneliti dalam mengungkap masalah yang terjadi dalam perkembangan surat kabar lokal yang ada di Madiun pada tahun 1999-2011. Sumber Data yang digunakan sumber data primer dan sekunder. Data Primer, dimana penelitian ini memperoleh informasi dari pimpinan redaksi, sekretaris dan koordinator lapangan dari masing-masing perusahaan surat kabar lokal yang ada di Madiun. Sedangkan data sekunder, dimana data ini digunakan untuk menguatkan teori yang digunakan dalam landasan peneliti dalam melakukan penelitian yang diperoleh dari referensi kepustakaan yang berfungsi menguatkan data yang diperoleh dari lapangan. Pengumpulan data menggunakan metode wawancara (interview), dokumentasi dan observasi lapangan. Dalam menganalisis data menggunakan metode wawancara (interview) dan penelitian lapangan (research). Analisis data yang digunakan adalah analisis data model interaktif Miles dan Huberman yang didalamnya terdapat 3 tahapan yaitu melalui proses reduksi data, sajian data dan verifikasi atau proses penarikan kesimpulan.

Berdasarkan hasil penelitian membuktikan bahwa perkembangan surat kabar lokal di Madiun dari tahun 1999-2011 mengalami perkembangan. Indikasi mengalami perkembangan adalah sudah tersebarnya surat kabar di wilayah Madiun secara merata, yang dulu hanya tersebar diwilayah kota saja. Informasi dari segala bidang (pendidikan, ekonomi, sosial budaya, politik dan kewirausahaan) dapat diperoleh oleh masyarakat dari berbagai golongan. Berkembang dan bertahanya surat kabar lokal di era modern ini juga merupakan bukti bahwa masyarakat juga masih percaya dengan surat kabar. Hasil penelitian yang lain menyebutkan bahwa surat kabar lokal memberikan pengaruh terhadap perkembangan Kota Madiun baik di bidang pendidikan, kewirausahaan, pemerintahan dan politik.
\end{abstract}

\section{Kata kunci : Pekembangan, Surat Kabar, Lokal}

\section{Pendahuluan}

Perkembangan pers di Indonesia sebagian besar dipengaruhi oleh adanya usaha percetakan dan penerbitan Belanda maupun Tionghoa, sebagian besar lagi dikarenakan munculnya elite Indonesia yang memerlukan media komunikasi. Pers merupakan tanda-tanda pertama perubahan masyarakat Indonesia, yang berkaitan dengan berkembangnya ekonomi, terutama dengan makin banyaknya usaha perekebunan dan semakin meluasnya perdangan, perkembangan politik, dan didirikan sekolah-sekolah model Belanda (Hilman Adil, 2002 : 9).

Memasuki era 1900-an, kualitas dan fungsi surat kabar meningkat. Bukan lagi sebatas sarana dokumentasi, tapi berkembang menjadi sarana menyampaikan saran, kritik, dan 
aspirasi, terutama bagi para pejuang kemerdekaan Indonesia. Medan Prijaji adalah surat kabar pertama yang terbit dan dikelola oleh orang Indonesia. Surat kabar berbahasa Indonesia dengan bahasan politik ini terbit pada Januari 1907. Pelopornya adalah Raden Mas Tirtoehadisoerjo. Surat kabar yang dirintis orang-orang Indonesia tidak bertahan lama karena kurangnya modal dan adanya pemberedelan yang dilakukan oleh negara penjajah. Pada saat Jepang kalah dalam Perang Dunia II dan terusir dari Indonesia pada 1945, Belanda, yang diboncengi oleh Inggris, kembali mencoba mengendalikan percetakan dan penerbitan surat kabar. Namun, berkat perjuangan Soekarno dan tokoh-tokoh pejuang lainnya, hal tersebut gagal. Bahkan, surat kabar Belanda ditutup dan perusahaan percetakan miliknya dinasionalisasi menjadi milik Indonesia. Pada 1946, surat kabar menemukan jati dirinya. Terbentuknya organisasi Serikat Penerbit Surat Kabar (SPS) pada Juni 1946, menyusul terbentuknya organisasi Persatuan Wartawan Indonesia (PWI) pada Febuari 1946. Hadirnya kedua organisasi ini setidaknya memberikan tujuan, visi, dan misi yang jelas bagi keberlanjutan surat kabar.
Pada masa orde lama dengan sistem pemerintahan demokrasi terpimpin, surat kabar yang isinya tidak sesuai dan sejalan dengan sistem pemerintahan akan dibredel dan dicabut ijin terbitnya. Sama halnya pada orde lama, pada orde baru surat kabar dipergunakan sebagai alat penguasa yang harus sejalan dengan pemerintah. Pembatasan surat kabar juga diterapkan oleh pemerintahan orde baru. Surat kabar yang dianggap berbahaya dan tidak sejalan dengan tujuan pemerintah akan dibredel, terlebih surat kabar yang menyinggung keluarga cendana dan kroni-kroninya. Kejadian ini bisa dilihat pada peristiwa pemberedelan majalah Tempo pada masa orde baru yang memuat masalah B.J. Habibie tentang pembelian kapal bekas dari Jerman (Asviwarman Adam, 2007:149).

$$
\text { Era reformasi adalah era }
$$
kebebasan pers, dimana pemerintah memberi kebebasan untuk tumbuh dan berkembang, baik pers cetak maupun elektronik. Kebebasan ini kemudian melahirkan raksasa-raksasa media, disebut raksasa karena hampir semua lini media digeluti: surat kabar, majalah, televisi, radio, dan website (surat kabar digital). Mereka adalah Kompas (Jacoeb Oetama), Jawa Pos (Dahlan Iskan), Media Indonesia (Surya Paloh), Media Nusantara Citra (Hary Tanusoedibjo), 
dan Tempo (Goenawan Mohamad). Luar biasanya, media mereka sampai ke daerah-daerah di seluruh Indonesia. Grup-grup besar ini memulai mengambil-alih surat kabar regional, dengan tujuan apabila Surat Izin Usaha Penerbitan Pers (SIUPP) surat kabar induk, misalnya Kompas atau Jawa Pos, dicabut oleh Pemerintah, masih ada surat kabar lain yang berkembang. Dalam rangka ini, surat kabar regional dapat dilihat sebagai diversifikasi grupgrup besar untuk mempertahankan diri dan melindungi kepentingannya.

Munculnya surat kabar (koran) daerah sebagian besar, terjadi di era reformasi, yaitu sejak tahun 1998. Koran daerah ini berbeda dari koran regional yang ada sebelumnya, dalam arti lebih lokal dan lebih bersifat kedaerahan. Munculnya dan berkembangnya koran daerah ini adalah imbas dari berkembangnya koran yang berkembang di kota-kota besar. Peraturan-peraturan pemerintah merupakan pengaruh terbesar terhadap koran daerah, tetapi bukan dalam arti perlindungan kepentingan, melainkan peraturan otonomi daerah yang meningkatkan kewibawaan dan kepentingan daerah.

Adanya imbas dari kota-kota besar tentang perkembangan pers khususnya media cetak (surat kabar/koran), koran yang ada di Madiun juga mengalami perkembangan. Perusahan surat kabar ternama seperti Jawa Pos melebarkan usahanya dengan mendirikan kantor rekanan yang berada didaerah-daerah, seperti di Madiun. Hal ini dapat mempengaruhi masyarakat Kota Madiun untuk mendirikan usaha dibidang jurnalistik khususnya surat kabar. Kondisi ini bisa dilihat dari banyaknya koran yang bermunculan dan beredar di Madiun, seperti Krida Rakyat, Memorandum, Radar Madiun (rekanan dari Jawa Pos), Suara Rakyat Mandiri dan Lawu Pos. Mulai koran yang terbit setiap hari sekali ataupun beredar secara mingguan. Adanya persebaran surat kabar baik yang dijual ditoko maupun yang berlangganan membuat informasi mudah diakses dan menyebar pada semua kalangan masyarakat Madiun. Selain beredar koran secara umum, ada juga koran atau majalah sekolah/kampus yang menghiasi perkembangan dan dinamika pers media cetak yang ada di Madiun. Bertolak dari uraian diatas maka peneliti terdorong untuk mengkaji dan meneliti dengan mengambil judul Perkembangan Media Cetak Surat Kabar (Koran) Di Madiun Pada Tahun 1999 2011.

\section{Tinjauan Pustaka}

1. Pengertian Surat Kabar 
Ide surat kabar usianya sudah

setua zaman romawi kuno, dimana setiap harinya, kejadian sehari-hari diterbitkan dalam bentuk gulungan yang disebut "Acta Diurna", yang terjamahan bebasnya adalah "kegiatan harian". Itulah surat kabar (koran) yang yang paling pertama dibuat oleh manusia. Setelah Gutenberg menemukan mesin cetak di abad ke 15 tepatnya pada tahun 1468, maka bukubuku mulai diterbitkan di Prancis dan Inggris, begitu pula dengan surat kabar yang sebelumnya hanya dituliskan pada lempengan-lempengan kayu oleh orang Cina (Edy Susanto, 2010:7).

Secara etimologis, surat kabar atau Koran berasal dari bahasa Inggris "newspaper" dan bahasa Belanda "caorante" yang dipinjam juga oleh orang Belanda dari bahasa Perancis "caorant". Henry Ward Beacher berpendapat bahwa koran adalah pendidik masyarakat banyak, koran adalah buku tanpa akhir yang menyangga kejayaan nasioanal kita (dalam Willian L Rivers, 2008:43). Surat kabar didevinisikan sebagai penerbitan yang berisi lembaran dan berisi beritaberita, karangan, iklan yang dicetak, serta terbit secara tepat atau periodikdan dijual untuk umum (Assegaf dalam Devi Aprilia, 2010:4-5). Menurut Cangara (dalam Dimas Agil,
2011:1) media cetak seperti majalah, buku, dan surat kabar (koran) justru mampu memberikan pemahaman yang tinggi kepada pembacanya, karena sarat dengan analisa yang mendalam dibandingkan media lain.

Surat kabar juga bisa disebut dengan media massa, karena memenuhi ciri-ciri komunikasi massa, yakni komunikasi menggunakan media massa yang berlangsung secara satu arah, komunikasinya melembaga, pesan bersifat umum, medianya menimbulkan keserempakan dan komunikasinya secara heterogen (Onong Uchjana,2009:145).

Dari berbagai pendapat di atas dapat disimpulkan bahwa surat kabar (koran) adalah lembaran-lembaran kertas yang bertuliskan tentang kabar berita yang berhubungan dengan topik terkini mengenai pendidikan, politik, keuangan, ekonomi, ataupun olahraga yang menyangkut dunia internasional, nasional dan lokal atau regional yang terbagi dalam kolom-kolom dan terbit setiap hari ataupun secara periodik.

\section{Fungsi Surat Kabar}

Pers dalam arti sempit yaitu menyangkut kegiatan komunikasi yang hanya dilakukan dengan perantara percetakan, sedangkan dalam arti luas menyangkut komunikasi yang dilakukan baik dari media cetak maupun 
elektronik, seperti majalah, surat kabar, televisi, internet maupun radio. Pers memiliki enam fungsi pokok, yaitu : (1) melayani system politik yang memungkinkan informasi, diskusi dan konsiderasi tentang masalah public yang dapat diakses oleh masyarakat; (2) memberikan informasi publik untuk memungkinkan publik bertindak bagi kepentingannya sendiri; (3) melindungi hak individu dengan bertindak sebagai anjing penjaga bagi pemerintah; (4) melayani sistem ekonomi melalui media iklan; (5) sebagai sarana hiburan; (6) memelihara otonomi dibidang finansial agar tidak tergantung kepada kepentingan dan pengaruh tertentu (Edy Susanto, 2010:30).

Menurut Dida Dirgahayu dan Neti Sumiaty (2007:3) secara umum surat kabar mempunyai fungsi :

a.Informasi (to inform), yaitu menyampaikan informasi secepatcepatnya kepada masyarakat dengan memenuhi kriteria dasar : aktual, akurat, faktual, menarik, penting, benar, lengkap-utuh, jelas-jernih, jujur-adil, berimbang, relevan, bermanfaat dan etis.

b.Edukasi (to educate), apapun yang disebarluaskan pers hendaknya dalam kerangka mendidik. Inilah yang membedakan pers dengan lembaga lain. Bagi masyarakat, pers harus menjadi watcher, teacher, and forum (pengamat, guru dan forum). Memberikan tinjauan atau analisis atas berbagai peristiwa dan kecenderungan yang terjadi, berperan dalam mewariskan nilai-nilai luhur universal, nilai-nilai dasar moral dan kandungan budaya lokal.

c. Koreksi (to control), sebagai media yang mempunyai fungsi koreksi, pers adalah pilar demokrasi keempat setelah legislatif, eksekutif dan yudikatif.

d.Rekreasi (to entertain), pers harus mampu memerankan dirinya sebagai wahana rekreasi yang menyenangkan sekaligus menyehatkan masyarakat.

e.Mediasi (to mediate), pers harus menjadi penghubung / fasilitator, Dengan pers kita mengetahui segala peristiwa lokal, regional, internasional dalam waktu singkat dan bersamaan.

\section{Jenis Surat Kabar}

Pers cetak sering juga disebut dengan media massa atau media cetak. Media cetak dapat diklasifikasikan menjadi beberapa bentuk, yaitu :

a. Surat kabar, yaitu kumpulan berita, artikel, cerita iklan dan sebagainya yang dicetak dalam lembaranlembaran kertas ukuran plano, terbit secara teratur dan setiap hari atau seminggu sekali. 
b.Majalah adalah kumpulan berita, artikel, iklan, dan sebagainya yang dicetak dalam kertas ukuran folio atau kuarto dan dijilid dalam bentuk buku. Majalah biasanya terbit secara teratur, seminggu sekali, dua minggu selaki atau sebulan sekali.

c. Tabloid adalah kumpulan berita, artikel, iklan, dan sebagainya yang dicetak dalam lembaran kertas broadsheet (lebih kecil dari plano) dan dilipat seperti surat kabar. Tabolid biasanya terbit secara teratur, seminggu sekali, dua minggu selaki atau sebulan sekali.

d.Buletin adalah berita, artikel, iklan, dan sebagainya yang dicetak dalam lembaran kertas broadsheet atau ukuran kuarto/plano dan dilipat seperti surat kabar. Penerbitan dari buletin tidak teratur sehingga sering disebut dengan penerbitan berkala.

e.Buku adalah tulisan tentang ilmu pengetahuan, essai, cerita-cerita panjang, kisah-kisah perjuangan dan sebagainya yang dicetak dalam lembaran kertas setengah kuarto atau setengah folio dan dijilid secara rapi (Totok Djuroto,2002:11).

Dari berbagai jenis media cetak David Wragg (2001:44-48) berpendapat bahwa surat kabar dapat dibedakan menjadi beberapa jenis, yaitu:

a. Surat Kabar Umum
Surat kabar umum merupakan surat kabar yang tidak dikhususkan untuk golongan tertentu. Surat kabar ini menentukan golongan berdasarkan wilayah peredarannya seperti surat kabar harian atau mingguan. Surat kabar pada jenis ini banyak merinci pada golongan kelas sosial, kecerdasan, aliran politik, masalah kekayaan/ekonomi dan surat kabar yang dikhususkan untuk perempuan. Surat kabar umum berisi tentang berbagai fitur-fitur diantaranya mengenai keuangan, politik, pertanian, perjalanan wisata, dan berita-berita tentang perkembangan.

b. Surat Kabar Nasional dan Regional

Surat kabar nasional adalah surat kabar yang terdiri dari surat kabar pagi dan beberapa surat kabar mingguan. Surat kabar regional sebagian besar memuat beritaberita internasional ataupun nasional selain mengangkat topik tentang berita regional ataupun lokal. Surat kabar regional memiliki sirkulasi kecil, dana yang terbatas dan sering kali membebankan seorang wartawan sebagai peliput berita dan sebagai editor dari berita yang dikutipnya.

c. Surat Kabar Lokal 
Jenis surat kabar yang ketiga surat kabar lokal, yakni surat kabar yang memberikan informasi pendidikan, politik, ekonomi dan masalah terkini dalam lingkup lokal. Sebagian besar surat kabar lokal diterbitkan mingguan dan bahkan ada juga yang diterbitkan dua minggu sekali. Untuk memuaskan pembacanya surat kabar lokal terbit dalam bentuk berseri. Surat kabar lokal memberikan kepercayaan lebih besar terhadap jaringan contributor yang tidak bayar yang menyediakan berita-berita tentang kejadian dan organisasi di tingkat lokal.

\section{d. Surat Kabar Terbitan Berkala}

\section{Khusus}

Surat kabar berkala khusus mencakup beraneka ragam kegiatan karena melayani pasar yang berbeda-beda. Bentuk surat kabar bermacam-macam mulai dari surat kabar hingga majalah yang menggunakan kertas mengkilap. Isi dari terbitan berkala juga bermacam-macam, dari beritaberita terkini, isu politik ataupun industri. Surat kabar berkala dijual di meja panjang, memiliki pasar yang terbatas dan kebanyakan pembaca memperolehnya dengan berlangganan. Kebanyakan surat kabar berkala ini dimiliki oleh perseorangan/pribadi dengan anggota tim editorial yang kecil dan meningkatkan kemampuan dengan mempekerjakan wartawan lepas yang memiliki keahlian-keahlian dalam bidangnya. Anggaran dana percetakan surat kabar berkala juga dibantu dari periklanan.

\section{Metode Penelitian}

Penelitian ini penulis memilih tempat penelitian di wilayah Kota Madiun. Waktu penelitian 4 bulan yang dimulai bulan februari tahun 2012. Pendekatan yang digunakan dalam penelitian ini adalah pendekatan kualitatif. Jenis pendekatannya adalah pendekatan studi kasus. Penelitian studi kasus ini dapat membantu peneliti dalam mengungkap masalah yang terjadi dalam perkembangan surat kabar lokal yang ada di Madiun pada tahun 1999-2011. Sumber Data yang digunakan sumber data primer dan sekunder. Data Primer, dimana penelitian ini memperoleh informasi dari pimpinan redaksi, sekretaris dan koordinator lapangan dari masingmasing perusahaan surat kabar lokal yang ada di Madiun. Sedangkan data sekunder, dimana data ini digunakan untuk menguatkan teori yang digunakan dalam landasan peneliti dalam melakukan penelitian yang 
diperoleh dari referensi kepustakaan yang berfungsi menguatkan data yang diperoleh dari lapangan.

Pengumpulan data menggunakan metode wawancara (interview), dokumentasi dan observasi lapangan. Dalam menganalisis data menggunakan metode wawancara (interview) dan penelitian lapangan (research). Analisis data yang digunakan adalah analisis data model interaktif Miles dan Huberman yang didalamnya terdapat 3 tahapan yaitu melalui proses reduksi data, sajian data dan verifikasi atau proses penarikan kesimpulan.

Analisis data penelitian ini menggunakan model analisis interaktif. Model analisis interaktif memungkinkan untuk melakukan pengumpulan data di lapangan dengan langsung menggunakan tiga komponen penelitian, yaitu reduksi data, penyajian data dan penarikan simpulan atau verifikasi(Sutopo, 2006:119).

\section{Hasil Penelitian}

\section{Perkembangan Media Cetak Surat Kabar Di Madiun Tahun 1999- 2011}

\section{a. Periode Tahun 1999-2005}

Surat kabar juga bisa disebut dengan media massa, karena memenuhi ciri-ciri komunikasi massa, yakni komunikasi menggunakan media massa yang berlangsung secara satu arah, komunikasinya melembaga, pesan bersifat umum, medianya menimbulkan keserempakan dan komunikasinya secara heterogen. Perkembangan setiap tahunnya di berbagai negara ataupun daerah juga berbeda, tergantung pada tingkat kepentingan dan fungsi dari surat kabar (koran).

Pasca reformasi kebebasan pers sudah dijamin dan dilindungi oleh hukum sehingga perkembangan surat kabar lokal berkembang dan menjamur diberbagai daerah. Di Madiun pasca reformasi surat kabar lokal harian dan mingguan mulai tumbuh dan menjamur. Surat kabar lokal yang ada di Madiun ada 4, tetapi yang masih aktif member kontribusi informasi kepada masyarakat ada 3 surat kabar yaitu Radar Madiun, Krida Rakyat dan Swara Rakyat Mandiri. Perkembangan surat kabar (koran) lokal di Madiun tidak sama, hal ini disebabkan karena masingmasing surat kabar mempunyai karakter tersendiri, fungsi dan pendistribusian. Radar Madiun sebagai pelopor surat kabar lokal yang ada di Madiun pertama terbit pada 12 Juli 1999 hanya mempunyai dua halaman yang mana berisi tentang berita-berita yang ada di Kota Madiun saja (wawancara dengan Muhammad Arif, Selasa 12 Juni 2012). 
Seiring dengan perkembangan dan minat baca masyarakat meningkat, sekarang Radar Madiun berkembang sebagai surat kabar harian yang yang sudah mencakup wilayah Karedenan Madiun. Format 2 halaman berkembang menjadi 6 halaman hingga sekarang menjadi 8 halaman dengan pemisahan berita sesuai berita lokal di Karesidenan Madiun (Radar Madiun, Radar Magetan, Radar Ponorogo, Radar Pacitan, Radar Ngawi dan Caruban Kota Baru). Pengklasifikasian berita berdasarkan daerah baru dilaksanakan pada 4 tahun terakir.

Setiap harinya oplah penjualan surat kabar Radar Madiun relatif, dengan rata-rata penjualan setiap harinya adalah 15 ribu eksemplar. Dalam satu tahun terakhir penjualan terbesar mencapai 20 ribu eksemplar. Penjualan koran dalam setiap harinya ramai pada hari Sabtu dan Minggu. Radar Madiun dalam pendistribusian surat kabar mempunyai 20 agen besar yang didistribusikan secara berfariasi. Agen dalam penjualan biasanya mempunyai pekerja untuk memasok pada kios-kios, mengantarkan pada langganan (perseorangan atau instansi pemerintah/swasta), dan sebagian menjual dijalan (di trafficlight atau dijual didalam bus). Harga eceran Radar Madiun Rp. 4000,- dan untuk berlangganan tiap bulanan berfariasi sesuai dengan kesepakatan pada agen, dengan rata-rata Rp.105.000,00 - Rp. 110.000,00 per bulan(wawancara dengan Dewi Sulistyani, Selasa 12 Juni 2012).

Harga yang relatif murah dengan berita yang lengkap membuat Radar Madiun menjadi faktor utama yang menyebabkan banyak diminati oleh masyrakat Madiun. Penampilan, kombinasi gambar/warna dan tata letak layout yang menarik membuat peminat pembaca tidak berkurang dan masih mempercayai Radar Madiun sebagai sumber informasi lokal. Secara keseluruhan instansi pemerintah, baik dari pendidikan sampai kantor pemerintah yang ada di Kota sudah berlangganan Radar Madiun.

Berita yang diinformasikan bersifat homogen, sesuai dengan isu dan topik berita yang terjadi di masingmasing daerah, mulai dari dunia pendidikan, sosial budaya, politik, ekonomi dan rubrik khusus tentang tips hidup, fasion ataupun sosok (seseorang yang bisa menginspirasi). Berbagai macam berita, masalah politik dan pemerintahan yang masih digemari oleh masyarakat. Radar Madiun juga menjalankan fungsinya sebagai media informasi yaitu sebgai kontrol sosial, sumber informasi dan hiburan. 
Berkibalat dari terbitnya Radar Madiun, Krida Rakyat sebagai surat kabar (koran) lokal yang ada di wilayah Karisidenan Madiun juga masih aktif dalam memberikan informasi kepada masyarakat. Krida Rakyat adalah surat kabar (koran) lokal yang terbit secara mingguan yang terbit pada hari Senin, yang mulai terbit pada 23 Oktober 2002 (wawancara dengan Atmaja Santo, Rabu 6 Juni 2012). Dalam perkembangannya Krida Rakyat juga mengalami perkembangan, yang mulanya hanya berupa mading yang ditempelkan di kantor-kantor desa, berkembang menjadi tabloid yang dikarenakan melihat minat masyarakat meningkat dan sekarang sudah berupa ukuran surat kabar (koran) penuh.

Surat kabar Krida Rakyat berbeda dengan Radar Madiun, Krida Rakyat berangkat dari daerah Kabupaten Madiun dan berkembang sampai ke Kota Madiun dalam penyajian berita dan pendistribusiannya. Dalam penyajian berita memfokuskan pada kehidupan masyarakat dalam mengembangkan usaha pertanian, pelaporan kegiatan desa, pencintraan seseorang yang dilakukan dalam pemilihan kepala desa (politik). Krida Rakyat tidak menyajikan berita yang bersifat kriminalitas dan mengkritik jalannya pemerintahan baik Kota maupun Kabupaten dikarenakan Krida Rakyat bersifat indenpenden dan tidak mempunyai ideologi khusus dalam menyajikan suatu berita. Secara umum sifat berita tidak menjatuhkan sebuah lembaga, tetapi murni sebagai sarana untuk menyampaikan informasi atau aspirasi secara positif, membangun, mencerdarkan dan sekaligus member solusi.

Dari awal terbit sampai sekarang mengalami perkembangan, surat kabar Krida Rakyat sudah mempunyai oplah 2000 eksemplar dalam satu kali terbit, dimana surat kabar dijual dengan harga eceran Rp. 2.500,00 (wawancara dengan Atmaja Santo, Rabu 6 Juni 2012). Berkembangnya jumlah produksi dikarenakan wilayah pendistribusian meluas sampai wilayah Karesidenan Madiun. Pendistribusian secara umum diberikan secara gratis kepada kantor desa, kantor pemerintahan ataupun pemesanan yang sudah berlangganan. Timbal balik yang didapatkan surat kabar (koran) Krida Rakyat memberikan biaya pemasangan iklan atau ucapan pada instansi pemerintah pada peringatan hari nasional, ucapan selamat atas keberhasilan seseorang dalam menjabat dalam pemerintahan atau pemasangan iklan usaha. Sistem pemasaran tersebut dilakukan agar 
surat kabar Krida Rakyat masih bisa aksis dalam memberikan informasi, hiburan kepada masyarakan Kota maupun Kabupaten Madiun .

\section{b. Periode Tahun 2006-2011}

Surat kabar lain yang masih tetap eksis memberikan informasi selain Radar Madiun dan Krida Rakyat adalah Swara Rakyat. Swara Rakyat adalah surat kabar lokal yang terbit seminggu sekali pada hari Senin yang mulai terbit pada 16 Oktober 2009 (wawancara dengan Darmanto, Rabu 5 Juni 2012). Swara Rakyat terbit dikarenakan ingin memunculkan lagi minat baca masyarakat dan belum adanya pendistribusian surat kabar sampai kepelosok diwilayah Kabupaten Madiun.

Perkembangan surat kabar Swara Rakyat sama seperti surat kabar lainnya, perkembangannya bertahap kearah yang lebih baik. Swara Rakyat penerbitan pertama sampai dengan penerbitan ke dua belas masih berbebtuk tabloid. Dikarenakan minat baca dan permintaan masyarakat akhirnya pada penerbitan yang ke tiga belas sudah berukuran penuh. Pertama terbit oplah dari Swara Rakyat per minggu hanya mencetak 500 eksemplar, tetapi sekarang bertambah menjadi 3500 eksemplar per minggu (wawancara dengan Darmanto, Rabu 5
Juni 2012). Faktor yang menyebabkan Swara Rakyat Mandiri berkembang adalah adanya tanggapan positif dari masyarakat, berita mengulas tentang berita-berita lokal, dan informasi yang diberikan kepada masyarakat secara gratis.

Swara Rakyat dalam penyajian berita disesuaikan dengan daerah, karena informasi lokal setiap daerah berbeda. Penyusunan tampilan berita dalam satu lembar terdiri dari 70\% berkaitan dengan berita iklan atau advetorial, $20 \%$ berkaitan dengan berita news (terkini dalam tiap daerah), dan $10 \%$ berkaitan dengan informasi kesehatan, pola dan gaya hidup masyarakat. Masalah yang di informasikan berkaitan dengan pendidikan, politik, sosial ekonomi ataupun kriminalitas baik dalam lingkup lokal maupun nasional (wawancara dengan Darmanto, Rabu 5 Juni 2012).

Lingkup pendistribusian surat kabar (koran) Swara Rakyat sudah mencakup Karisedenan Madiun. Pembiayaan produksi Swara Rakyat sebagaian besar sudah ditutup dari biaya advetorial (iklan), sehingga sebagian masih dibagikan secara gratis didaerah. Banyak dari intansi pemerintah yang memasang iklan, memberi ucapan selamat ataupun mempromosikan sekolahnya agar dapat 
diketahui oleh masyarakat. Biaya pemasangan iklan yang relatif murah, menjadikan Swara Rakyat mempunyai banyak relasi. Swara Rakyat dibagikan secara gratis di daerah Madiun, Caruban, Pacitan, Nganjuk, Magetan dan sudah mulai dijual di daerah Ngawi dengan harga Rp. 15.000,00 per bulan dengan estimasi satu eksemplar adalah Rp. 3.250,00 . Di setiap daerah pendistribusian sudah ada agen untuk memasarkan surat kabar Swara Rakyat (wawancara dengan Darmanto, Selasa 5 Juni 2012).

$$
\text { Swara Rakyat juga }
$$

menjalankan fungsinya sebagai media massa yang dapat memberikan informasi secara tepat kepada masyrakat, memberikan hiburan dan sebagai kontrol dalam roda pemerintahan. Swara Rakyat sebagai surat kabar yang menjadi wadah menyampaikan informasi yang dilakukan oleh masyarakat untuk pemerintah.

$$
\text { Fungsi mempengaruhi }
$$
menyebabkan surat kabar (koran) memegang peranan penting dalam masyarakat. Pada fungsi ini, dimanfaatkan oleh para calon pemimpin (Kota dan Kabupaten) dalam peningkatan citra atau nama baik dengan membuat artikel, semboyan atau selogan dan ucapan selama pada hari-hari nasional. Sehingga secara keseluruhan surat kabar (koran) lokal yang beredar di kawasan Kota Madiun mengalami penjualan/oplah yang bayak pada saat peringatan hari nasional dan pemilihan umum, baik dari tingkat pemerintahan pusat sampai pencintraan kepaala desa. Kenaikan jumlah produksi surat kabar (koran) di Madiun meningkat 50\%-100\% yang difungsikan sebagai sarana kampanye.

Penelitian perkembangan koran yang ada di Madiun ini juga di dukung data dari penelitian yang dilakukan oleh WAN-IFRA (Word Association of Newspapers and News Publisher), gelaran asosiasi surat kabar (koran) dan penerbitan sedunia yang dilakukan pada hari Selasa 10 April 2012 di Nusa Dua Bali mengatakan bahwa publik/masyarakat masih mempercayai kepada surat kabar (koran) sebagai sarana untuk mendapatkan informasi. Survei yang dilakukan oleh Edelman Trust Barometer yang merupakan survei global tahunan yang diadakan sejak 12 tahun silam dengan melibatkan 30 ribu responden di 25 negara. Termasuk negara yang dilakukan sebagai objek penelitian adalah Malaysia, Australia, Singapura, Jepang, Korea Selatan, Tiongkok, Hongkong, dan India. 
Berdasarkan hasil penelitian yang dilakukan oleh Edelman Trust Barometer pada tahun 2012 menyatakan tingka kepercayaan publik terhadap media di Indonesia mencapai 80\%. Hasil penelitian ini merupakan tingkat kepercayaan publik tertinggi dibandingkan dengan hasil survei di 24 negara lain. Bahkan angka tersebut melampoi tingkat kepercayaan media dimata masyarakat dunia secara umum yang hanya 53\%, juga pulik Asia Pasifik yang hanya mencapai 63\%. Berdasarkan survey itu pula, surat kabar (koran) tercatat 48\% masih dipercaya dibandingkan dengan media konvensional lainnya seperti radio, televise, dan internet (Kris Moerwanto, 2012:4).

Penelitian yang lain dilakukan oleh lembaga riset mutakhir yang ada di Australia, yakni Roy Morgan. Hasil penelitian dari Roy Morgan menyatakan dalam survey kepembacaan surat kabar (koran) yang ada di 20 kota utama dan 22 kota sekitarnya di 16 provinsi seIndonesia turunnya animo masyarakan terhadap surat kabar (koran) hingga 15 persen selama setahun terkhir ini ternyat berbanding terbalik dengan yang terjadi di Provinsi Jawa Timur dan daerah luar Jawa.

Di Jawa Timur angka kepembacaan surat kabar (koran) setahun terakhir bertamabah menjadi 50,7 persen. Meningkat dari 3,4 juta orang menjadi 5,2 juta orang. Angka kepembacaan surat kabar (koran) di Provinsi Sumatra Utara, Riau, Sumatra Barat, Sumatra selaatan, Lampung dan Sulawesi Selatan tercatat berlipat menjadi 186 persen. Pertumbuhan kepembacaan surat kabar (koran) di daerah-daerah mengindikasikan minat baca public. Artinya ada kebutuhan dari masyarakat atas informasi, berita dan pesan yang terpecaya(Kris Moerwanto, 2012:4).

Perkembangan minat baca pada surat kabar (koran) yang ada di Provinsi Jawa Timur juga berdampak di Kota Madiun. Hal ini bisa dilihat dari berkembangannya industri surat kabar (koran) yang ada di Madiun. Bertahan dan berkembangnya surat kabar (koran) lokal dengan memberikan inovasi dalam setiap penerbitannya membuat surat kabar (koran) lokal masih diminati oleh masyarakan di Kota Madiun 


\begin{tabular}{|c|c|c|c|c|}
\hline \multicolumn{5}{|c|}{ Tabel 1 : Sirkulasi Penjualan Surat Kabar Lokal Di Madiun } \\
\hline \multirow[b]{2}{*}{ No } & \multirow[b]{2}{*}{ Keterangan } & \multicolumn{3}{|c|}{ Surat Kabar(Koran) Lokal } \\
\hline & & $\begin{array}{l}\text { Radar } \\
\text { Madiun }\end{array}$ & $\begin{array}{c}\text { Krida } \\
\text { Rakyat }\end{array}$ & $\begin{array}{c}\text { Swara } \\
\text { Rakyat }\end{array}$ \\
\hline 1 & Tahun 1999-2005 & & & \\
\hline & a. Jumlah halaman & $2-4$ & $2-4$ & - \\
\hline & b. Harga (dalam Rp.) & $1500-2000$ & Gratis & - \\
\hline & c. Jumlah Cetak (oplah) & $1000-8000$ & $1000-1500$ & - \\
\hline & d. Pendistribusian & Madiun & Kab.Madiun & - \\
\hline 2 & Tahun 2006-2011 & & & \\
\hline & a. Jumlah halaman & $4-8$ & $4-12$ & $4-12$ \\
\hline & b. Harga (dalam Rp.) & $2.500-4.000$ & Gratis-2000 & Gratis-3500 \\
\hline & c. Jumlah Cetak (oplah) & $8000-15000$ & $1000-2000$ & $500-3500$ \\
\hline & d. Pendistribusian & $\begin{array}{l}\text { Karesidenan } \\
\text { Madiun }\end{array}$ & $\begin{array}{l}\text { Karesidenan } \\
\text { Madiun }\end{array}$ & $\begin{array}{l}\text { Karesidenan } \\
\text { Madiun, } \\
\text { Nganjuk }\end{array}$ \\
\hline
\end{tabular}

c. Pengaruh Surat Kabar Terhadap Perkembangan Kota Madiun Tahun 1999-2011

Pasca reformasi sampai dengan sekarang ini, perkembangan media massa/pers memberikan dampak yang signifikan terhadap pemerintahan. Adanya kebebasan setelah reformasi dan jaminan perlindungan dari pemerintah, membuat media massa menjamur sampai dipelosok desa. Banyak media-media yang berkembang yang memberikan sarana informasi kepada masyarakat, mulai dari media elektronik sampai media cetak. Seiring perkembangan zaman, berbagai media pun juga mengalami perkembangan baik cetak maupun elektronik.

Perkembangan surat kabar (koran) lokal yang ada di Madiun baik yang mempunyai kantor diwilayah
Kabupaten memberikan dampak positif bagi kemajuan Kota Madiun. Persebaran informasi menjadi indikasi pertama yang yang menunjukan peranan dari surat kabar. Tumbuh dan berkembangnya surat kabar (koran) lokal membuat informasi dapat tersebar secara merata dikawasan Karisidenan Madiun. Pengaruh surat kabar (koran) di Madiun dapat terlihat di berbgai bidang, diantaranya:

\section{Bidang Pendidikan}

Peran surat kabar lokal dibidang pendidikan dimanfaatkan sebagai sarana publikasi dan dokumentasi untuk mempromosikan sekolah dengan tujuan agar dikenali oleh masyarakat sehingga mendapatkan input ketika penerimaan siswa pada tahun ajaran baru. Perguruan Tinggi 
Negeri yang ada di Madiun juga memanfaatkan surat kabar lokal untuk mendapatkan mahasiswa.

Guru dan Dosen juga memanfaatkan surat kabar (koran) lokal sebagai media untuk mempublikasikan tulisan ilmiah, artikel ataupun opini dengan mengganti biaya cetak yang relatif murah, yang biasanya sebagai syarat kenaikan pangkat atau untuk mempeoleh tunjangan tertentu dari pemerintah ataupun dari pihak tertentu.

Surat kabar memberikan sumber informasi kepada para siswa tentang berita-berita yang ada di lingkup lokal ataupun nasional. Penggunaan surat kabar dalam dunia pendidikan biasanya digunakan sebagai kliping. Berita tentang wawasan nusantara dan kearifan lokal dapat memberikan wawasan umum kepada siswa.

\section{Bidang Politik}

Komunikasi massa adalah pesan yang dikomunikasikan melalui media yang ditunjuk kepada khalayak dalam jumlah besar (Dwi Nurhyas, 2010:19). Surat kabar (koran) lokal di Madiun sebagai sarana komunikasi massa yang dapat membentuk dan mempengaruhi opini publik. Masyrakat dari berbagai kalangan dan dari tingkat pendidikan yang rendah pun mudah untuk mengaksesnya. Daya nalar dan logika yang terbataslah yang membuat pembentukan opini bisa berjalan dengan sukses, sehingga dengan adanya keadaan tersebut, masyarakat dapat mengikuti berbagai perkembangan informasi yang ada di daerah (lokal) ataupun di pemerintahan pusat.

Hal ini dimanfaatkan oleh para politisi sebagai media untuk mengkampanyekan dirinya (perbaikan citra individu) dalam pemilihan kepala pemerintahan, baik daerah, kota maupun anggota dewan legeslatif. Surat kabar (koran) lokal membantu proses berjalannya demokrasi di wilayah lokal dengan menempatkan sebagai media kampanye. Pada musim kampanye, oplah dari surat kabar lokal meningkat dari produksi biasanya.

\section{Bidang Pemerintahan}

Sebagai sarana informasi yang sudah dapat terjangkau oleh masyarakat yang ada di pelosok desa, dengan harga yang cukup murah membuat sosialisai ataupun himbauanhimbauan dari program pemerintah (kesehatan, pendidikan dan pembangunan) dapat tersebar secara merata dengan bahasa yang mudah dimengerti dari berbgai kalangan masyarakat. 
Surat kabar (koran) sebagai media massa yang mempunyai fungsi sebagai kontrol sosial sehingga jalan dan berkembangnya pemerintah diikuti oleh masyarakat kota Madiun. Surat kabar juga sebagai sarana untuk menyampaikan aspirasi, saran yang membangun kepada wakil rakyat untuk kemajuan Kota Madiun.

\section{Bidang Usaha}

Surat kabar lokal juga
digunakan oleh masyarakat Kota
Madiun sebagai media iklan dari usaha
yang didirikan dan dikembangkannya.
Biaya iklan/advertorial yang relatif

\section{Simpulan dan Saran}

\section{Simpulan}

Surat kabar (koran) merupakan penyebar informasi pada khalayak. Perkembangan surat kabar (koran) lokal di Kota Madiun paska reformasi sampai sekarang mengalami perkembangan yang cukup pesat. Letak yang strategis membuat arus perkembangan informasi dan perkembangan dari kota-kota besar berimbas di Madiun. Adanya kebebasan dan perlindungan terhadap pers, membuat surat kabar (koran) lokal mulai menjamur diberbagai daerah. Berdirinya tiga perusahaan surat kabar terjangkau untuk mempromosikan usahanya. Pemerintah juga memanfaatkan sebagai saran publikasi dari makanan khas daerah, seperti brem, pecel Madiun dan sate khas Ponorogo.

Bagi kalangan petani juga dimanfaatkan untuk mengetahuhui perkembangan informasi harga dari hasil panen sehingga dapat mengantisipasi adanya kecurangan dari para tengkulak. Adanya informasi dunia pertanian dan perkebunan juga mempermudah petani dalam memasarkan hasil panennya.

(koran) lokal seperti Radar Madiun, Krida Rakyat dan Swara Rakyat Mandiri membuat informasi tersebar merata di kawasan Madiun. Perkembangan dari berbagai bidang, baik politik, ekonomi, sosial, pendidikan dan pertanian dapat diakses dengan mudah, biaya yang relatif murah dan dengan bahasa yang mudah dimengerti.

Surat kabar (koran) lokal juga mempunyai pengaruh terhadap perkembangan Kota Madiun. Sebagai sarana publikasi yang relatif murah dimanfaatkan dalam dunia pendidikan untuk mempromosikan sekolah, para calon pemimpin juga memanfaatkan surat kabar (koran) sebagai media 
kampanye (pencintraan individu), banyak juga masyarakat Madiun yang mempromosikan usahanya dan sebgai kontrol terhadap jalannya pemerintahan Kota Madiun. Sehingga segala aktifitas dan perkembangan pemerintah masyarakat dapat mengetahuinya begitu juga sebaliknya.

\section{Saran}

\section{a.Bagi Masyarakat Kota Madiun}

Beredarnya surat kabar (koran) lokal membantu masyarakat dalam memperoleh informasi dari berbagai pemerintah serta himbauanhimbauan baik dibidang kesehahtan dan pendidikan. Deangan adanya komunikasi yang berjalan dengan baik dengan masyarakat maka pemerintah mudah menjalankan programprogramnya.

Pemerintah tetap menjalin hubungan yang baik dengan surat kabar (koran) lokal yang ada di Kota Madiun karena surat kabar adalah media komunikasi massa yang efektif, murah dan dengan bahasa yang mudah dipahami masyarakat.

\section{c. Bagi Surat Kabar Radar Madiun,} Krida Rakyat dan Swara Rakyat

Perusahaan surat kabar (koran) lokal masih terus aksis dan bertahan dalam mengawal jalannya pemerintahan dan menjalankan fungsinya sebagai fungsi kontrol sosial, bidang. Hendaknya masyarakat memanfaatkan surat kabar (koran) lokal sebagai wadah untuk menyampaikan kritik dan saran yang membangun untuk kemajuan Kota Madiun.

\section{b. Bagi Pemerintah Kota Madiun}

Adanya surat kabar (koran) lokal yang terbit harian dan mingguan dapat dimanfaatkan oleh pemerintah dalam menyampaikan programprogram

wadah informasi, sarana publikasi dan hiburan dengan harga yang relative murah dengan bahasa yang mudah dicerna oleh masyarakat.

\section{Daftar Pustaka}

Arek Jurnalistik Kreatip. 2010. Kuda Troya Media Masa. Malang: Departemen Ilmu Komunikasi

Arief Furchan. 1992. Pengantar Metode Penelitian Kualitatif. Surabaya: Usaha Nasional

Asvi Warman Adam. 2007. Seabad Kontroversi Sejarah. Yogyakarta: Ombak.

Badan Pusat Statistik. 2011. Kota Madiun Dalam Angka 2011. Madiun: CV Aneka Surya

Basri MS. 2006. Metode Penelitian Sejarah. Jakarta: Restu Agung

Bedjo Riyanto. 2000. Iklan Surat Kabar.Yogyakarta: Tarawang

Deddy Iskandar Muda. 2005. Jurnalistik Televisi menjadi Reporter Profesional. Bandung: PT Remaja Posdakarya 
Devi Aprilia. 2010. Sikap Pegawai Pemerintah Kota Surabaya Tentang Pemberitaan Peraturan Daerah Kota Surabaya No.5 Tahun 2008 Tentang Kawasan Tanpa Rokok Dan Kawasan Terbatas Merokok Pada Harian Surat Kabar Jawa Pos. Skripsi tidak diterbitkan. Surabaya: Universitas Pembangunan Nasional "Veteran" Surabaya.

Dida Dirgahayu, Nety Sumiaty. Tanpa tahun. Pendapat Kecamatan Metro Pusat Tentang Fungsi Surat Kabar, http:// isjd.pdii.lipi.go.id.adminjurnal 5082950.pdf diunduh tanggal 1 Maret 2012.

Dimas Agil Pribadi. 2011. Pemaknaan Karikatur Pada Surat Kabar Kompas. Skripsi tidak diterbitkan. Surabaya: Universitas Pembangunan Nasional "Veteran" Surabaya.

Edy Susanto. dkk. Hukum Pers di Indonesia. Jakarta: PT RINEKA CIPTA

Emy Susanti. 2008. Metode Penelitian Sosial: Berbagai Alternatif Pendekatan. Dalam Bagong Suyanto dan Sutinah (eds). Jakarta: Kencana

Emzir. 2011. Metodologi Penelitian Kualitatif Analisis Data. Jakarta Utara: PT. Radja Grafindo Persada

Fachrul Khairuddin. 2011. Surat Kabar Di Indonesia, http://kompasiana.connecting.h tml diunduh tanggal 1 Maret 2012.

Faizal Oktaf. 4 Mei 2010. Kelebihan dan Kekurangan Media Iklan, faizal_oktaf@webmail.umm.ac.id diunduh tanggal 1 Maret 2012
H.B Sutopo. 2006. Metodologi Penelitian Kualitatif. Surakarta: Universitas Sebelas Maret.

Hilman Adil.dkk. 2002. Beberapa Segi Perkembangan Sejarah Pers Di Indonesia. Jakarta: PT Kompas Media Nusantara

Husaini Usman dan Purnomo Setiady Akbar. 2004. Metodologi Penelitian Sosial. Jakarta: PT. Bumi Aksara

Joko Subagyo. 2004. Metode Penelitian. Jakarta: PT.Rineka Cipta

Kris Moerwanto. 2012, 10 April. Publik Masih Percaya Koran. Jawa Pos , halaman 4.

L. Rivers William. 2008. Media Massa dan Masyarakat Modern. Jakarta: Kencana

Onong Uchjana Effendy. 2009. Ilmu Komunikasi Teori dan Praktek. Bandung: PT Remaja Posdakarya

Rianto Adi. 2005. Metodologi Penelitian Sosial dan Hukum. Jakarta: Granit

Sugiyono. 2009. Metode Penelitian Kuantitatif, Kualitatif dan $R \& D$. Bandung: CV ALFABETA

Sugiyono. 2012. Memahami Penelitian Kualitatif. Bandung: AIFBETA CV

Suharsimi Arikunto. 2010. Prosedur Penelitian. Jakarta : PT Rinekacipta

Sukri Abdurrrachman. 2003. Krisis Masa Kini dan Orde Baru. Jakarta: Yayasan Obor Indonesia.

Totok Djuroto. 2002. Manajemen Penerbitan Pers. Bandung: PT Remaja Posdakarya

Tri Rangga. dkk.2010. Media Dengarkan $A k u$. Malang: KAKI-KOE

Wragg David. dkk. 2001. Hubungan Media Yang Efektif. Terjemahan oleh Syahrul. 2004. Jakarta: Erlangga 
